\title{
Building a Maternal and Newborn Care Training Programme for Health-Care Professionals in Guinea- -Bissau
}

\author{
Desenvolvimento de um Programa de Treino em \\ Cuidados de Saúde Materna e Assistência ao Recém- \\ Nascido para Profissionais de Saúde na Guiné-Bissau
}

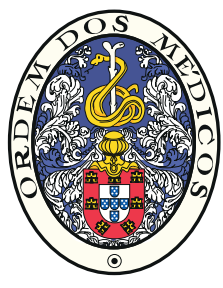

\author{
Ana REYNOLDS $\square^{1,2}$, Ahmed ZAKY ${ }^{3}$, Joana MOREIRA-BARROS ${ }^{4}$, João BERNARDES ${ }^{1,5}$ \\ Acta Med Port 2017 Oct;30(10):734-741 - https://doi.org/10.20344/amp.8453
}

\section{ABSTRACT}

Introduction: The Integrated Programme of Maternal and Child Health aims to reduce maternal and child mortality in Guinea-Bissau. The purpose of this article is to share our experience in building a training programme on maternal and newborn care for health-care professionals in Guinea-Bissau.

Material and Methods: Regional directors of the four target areas chose a group of staff who provide prenatal and childbirth care to attend the course (12 to 15 trainees per region). In each region, 15 highly interactive and practical sessions were scheduled over eight weeks. The trainees' summative and reactive assessment was obtained using a multiple choice questionnaire (final test) and an anonymous survey, respectively.

Results: Attendees included 25 nurses, 17 midwives and 14 doctors. About two thirds had five years' practice or less. Test median scores were higher among trainees with two to nine years of practice $(54.4 \%$ to $60.9 \%)$, as compared to those with a year or less $(47.8 \%)$ or 10 or more years $(45.7 \%)$. Pedagogical variables were rated as 'good' or 'very good' by $91 \%$ to $95 \%$ of the attendees.

Discussion: Use of an interactive and practical pedagogical methodology produced positive results and was crucial to tailoring the training to local needs. However, adapting the syllabus according to professional categories and experiences should be considered.

Conclusion: Our results warrant further development and evaluation of training programmes on maternal and neonatal care in GuineaBissau.

Keywords: Education, Continuing; Guinea-Bissau; Health Promotion; Infant Health; Maternal Health; Quality of Health Care; Staff Development

\section{RESUMO}

Introdução: O Programa Integrado de Saúde Materna e Infantil visa reduzir a mortalidade materno-infantil na Guiné-Bissau. O objetivo deste artigo é partilhar a experiência no desenvolvimento do treino em cuidados maternos e ao recém-nascido, em quatro regiões da Guiné-Bissau.

Material e Métodos: Os diretores regionais indicaram 12 a 15 profissionais que prestavam assistência pré-natal e ao parto para participarem no treino. Durante oito semanas, 15 sessões predominantemente interativas e práticas foram ministradas em cada região. Foram efetuadas avaliações sumativa e reativa através de um teste final com perguntas de escolha múltipla e de um questionário de satisfação anónimo, respetivamente.

Resultados: Participaram no treino 25 enfermeiras, 17 parteiras e 14 médicos. Praticamente dois terços tinham cinco ou menos anos de prática clínica. Os resultados do teste final foram superiores nos formandos com dois a nove anos de experiência (medianas de $54,4 \%$ a $60,9 \%)$, comparativamente àqueles até um ano $(47,8 \%)$ ou com 10 ou mais anos $(45,7 \%)$. As variáveis pedagógicas foram classificadas como 'bom' ou 'muito bom' por $91 \%$ a $95 \%$ dos participantes.

Discussão: A metodologia interativa e prática produziu bons resultados e foi muito útil para moldar o treino às necessidades locais. Contudo, o programa de estudos deve ser adaptado de acordo com categorias e experiências profissionais.

Conclusão: Os resultados obtidos justificam o desenvolvimento e a avaliação adicional de programas de formação em cuidados de saúde materna e neonatal na Guiné-Bissau.

Palavras-chave: Desenvolvimento de Pessoal; Educação Contínua; Guiné-Bissau; Promoção da Saúde; Qualidade da Assistência à Saúde; Saúde Infantil; Saúde Materna

\section{INTRODUCTION}

The Republic of Guinea-Bissau (RG-B) is a developing Sub-Saharan African country. Since its independence in 1974, there has been considerable socio-economic population's well-being, such as poor access to basic healthcare. Recent data available at the World Bank database ${ }^{1}$ reveal that the RG-B has one of the lowest levels instability, leading to disastrous consequences for the of per capita gross domestic product in the world.

\footnotetext{
1. Centro de Investigação em Tecnologias e Serviços de Saúde (CINTESIS). Departamento de Ginecologia-Obstetrícia e Pediatria. Faculdade de Medicina. Universidade do Porto. Porto. Portugal.

2. Centro de Simulação Médica do Porto (Cesimed). São Mamede de Infesta. Portugal.

3. Instituto Marquês de Valle Flôr. Lisboa. Portugal.

4. Serviço de Ginecologia e Obstetrícia. Departamento da Mulher, da Criança e do Jovem. Hospital de Pedro Hispano. Unidade Local de Saúde de Matosinhos. Senhora da Hora. Portugal.

5. Departamento da Mulher, da Criança e do Jovem. Hospital de Pedro Hispano. Unidade Local de Saúde de Matosinhos. Senhora da Hora. Portugal.

$\triangle$ Autor correspondente: Ana Reynolds. reynolds@med.up.pt

Recebido: 09 de novembro de 2016 - Aceite: 27 de junho de 2017 | Copyright @ Ordem dos Médicos 2017 
Despite all the investment that has been made, data regarding maternal and child health worldwide reveal a serious situation, and in the RG-B the scenario is very poor. Maternal, neonatal, infant and under-5 mortality in this country far exceed the global average. Not surprisingly, the RG-B's birth and fertility rates are double the global rates. Furthermore, existing health resources are tremendously scarce, particularly human resources (Table 1).

Leading causes of maternal death in the RG-B have been post-partum haemorrhage (42\%), labour dystocia (19\%), infection (16\%), abortion (9\%) and eclampsia (6\%). ${ }^{2}$ Guinea's causes of maternal mortality are similar to those found in other Sub-Saharan developing countries, ${ }^{3}$ stressing the need to assess obstacles, from the community to the level of health care provision. In children up to five years old, the major causes of death are neonatal complications $(24 \%)$ as a result of prematurity, asphyxia and sepsis ${ }^{2}$.

The need to scale up skilled birth attendance in these settings has long been recognised, and is perceived as care by an "accredited health professional - such as a midwife, doctor or nurse - who has been educated and trained to proficiency in the skills needed to manage normal (uncomplicated) pregnancies, childbirth and the immediate postnatal period, and in the identification, management and referral of complications in women and newborns". ${ }^{4}$ As expected, the scaling up of qualified health personnel in 58 low- and middle-income countries has proved to be central to attaining the best cost-effectiveness considering associated expenses and deaths averted, as well as to obtaining an effective reduction in maternal, foetal and newborn mortality, when covering $99 \%$ or up to $60 \%$ of the population. ${ }^{5} \mathrm{~A}$ better impact would be obtained if family planning services were included.

The Integrated Programme of Maternal and Child Health [Programa Integrado de Saúde Materno-infanti], $(\mathrm{PIMI})^{2}$ aimed to reduce maternal and under-5 mortality in the Biombo, Cacheu, Oio and Farim regions, located in northern RG-B. Starting on July 152013 , the programme ran for three years. It was co-financed by the European Union and all executants, including the United Nations Children's Fund (UNICEF), Entraide Médicale Internationale (EMI) and Instituto Marquês de Valle Flôr (IMVF). The IMVF, a Portuguese NGO, was also supported by the Camões Institute of Cooperation and the Calouste Gulbenkian Foundation. Target regions comprised two regional hospitals and 40 health units with different levels of care, depending on doctor availability and existing conditions for surgery.

The PIMI was classified as being of public interest by the Portuguese authorities. Obstetrics \& Gynecology residents were also given the opportunity to collaborate as an optional internship by the Portuguese Medical Association's Obstetrics \& Gynecology College.

The IMVF's core actions under the PIMI included: (1) Technical assistance - 'on-the-job' and 'in-class' capacity building of local health staff delivering maternal and under-5 care; (2) Assuring availability of drugs/medication, medical consumables, surgical instruments and equipment, following a gratuity grid aligned with established impact interventions; (3) Supporting the development of a referral system among different levels of care; (4) Promoting blood transfusion availability; and (5) Improving infrastructures in both regional hospitals and some health units, such as access to water and electricity. The clinical team working for the PIMI included permanent staff (fixed clinical staff)

Table 1 - Comparison of key reproductive health development indicators in Guinea-Bissau (RG-B) and the world (W)*

\begin{tabular}{|c|c|c|c|}
\hline Health development indicator & $\begin{array}{l}\text { Guinea-Bissau } \\
\text { (year) }\end{array}$ & $\begin{array}{l}\text { World } \\
\text { (year) }\end{array}$ & $\begin{array}{l}\text { RG-B versus W } \\
\text { RG-B / W }\end{array}$ \\
\hline $\begin{array}{l}\text { Life expectancy at birth, total } \\
\text { (years) }\end{array}$ & $\begin{array}{l}55.16 \\
(2014)\end{array}$ & $\begin{array}{l}71.45 \\
(2014)\end{array}$ & 0.77 \\
\hline $\begin{array}{l}\text { Birth rate, crude } \\
\text { (per } 1000 \text { people) }\end{array}$ & $\begin{array}{l}37.09 \\
(2014)\end{array}$ & $\begin{array}{l}19.34 \\
(2014)\end{array}$ & 1.92 \\
\hline $\begin{array}{l}\text { Fertility rate, total } \\
\text { (births per woman) }\end{array}$ & $\begin{array}{l}4.83 \\
(2014)\end{array}$ & $\begin{array}{l}2.45 \\
(2014)\end{array}$ & 1.97 \\
\hline $\begin{array}{l}\text { Mortality ratio, MATERNAL } \\
\text { (modeled estimate, per } 100000 \text { live births) }\end{array}$ & $\begin{array}{l}549 \\
(2015)\end{array}$ & $\begin{array}{l}216 \\
(2015)\end{array}$ & 2.54 \\
\hline $\begin{array}{l}\text { Mortality rate, NEONATAL } \\
\text { (per } 1000 \text { live births) }\end{array}$ & $\begin{array}{l}39.7 \\
(2015)\end{array}$ & $\begin{array}{l}19.2 \\
(2015)\end{array}$ & 2.07 \\
\hline $\begin{array}{l}\text { Mortality rate, INFANT } \\
\text { (per } 1000 \text { live births) }\end{array}$ & $\begin{array}{l}60.3 \\
(2015)\end{array}$ & $\begin{array}{l}31.7 \\
(2015)\end{array}$ & 1.90 \\
\hline $\begin{array}{l}\text { Mortality rate, UNDER-5 } \\
\text { (per } 1000 \text { live births) }\end{array}$ & $\begin{array}{l}92.5 \\
(2015)\end{array}$ & $\begin{array}{l}42.5 \\
(2015)\end{array}$ & 2.18 \\
\hline $\begin{array}{l}\text { Hospital beds } \\
\text { (per } 1000 \text { people) }\end{array}$ & $\begin{array}{l}1 \\
(2009)\end{array}$ & $\begin{array}{l}2.92 \\
(2005)\end{array}$ & 0.34 \\
\hline $\begin{array}{l}\text { Nurses and midwives } \\
\text { (per } 1000 \text { people) }\end{array}$ & $\begin{array}{l}0.55 \\
(2010)\end{array}$ & $\begin{array}{l}3.28 \\
(2011)\end{array}$ & 0.17 \\
\hline $\begin{array}{l}\text { Physicians } \\
\text { (per } 1000 \text { people) }\end{array}$ & $\begin{array}{l}0.05 \\
(2010)\end{array}$ & $\begin{array}{l}1.54 \\
(2011)\end{array}$ & 0.03 \\
\hline $\begin{array}{l}\text { Births attended by skilled health staff } \\
\text { (\% of total) }\end{array}$ & $\begin{array}{l}45 \\
(2014)\end{array}$ & $\begin{array}{l}70.06 \\
(2012)\end{array}$ & 0.64 \\
\hline
\end{tabular}

\footnotetext{
${ }^{*}$ based on data from the World Bank ${ }^{1}$
} 
and short-term collaborators (rotating clinical staff). An educational intervention on Obstetric and Neonatal Urgent Care (Cuidados Obstétricos e Neonatais de Urgência), or simply 'CONU', was developed as part of the 'in-class capacity building'.

The aim of this study is to share our experience in building the CONU training programme as well as to evaluate its usefulness while trying to identify factors that may affect its impact.

\section{MATERIAL AND METHODS}

\section{Development of CONU: planning, implementation and} execution

The CONU training course was conceived in close dialogue with local health authorities, taking into account (1) A far more comprehensive programme, the PIMI, aimed at improving maternal and child health; (2) Resources made available by the programme; (3) Existing local resources; (4)
Health system organisation in the RG-B; and (5) Available budget for this activity.

The established goals for the training course were: (1) To reinforce cognitive, technical and non-technical skills needed to provide urgent maternal and newborn care; (2) To introduce foetal surveillance technologies (basics of foetal heart rate monitoring); (3) To introduce/strengthen on-the-job capacity building of diagnostic and therapeutic tools made available by the PIMI (e.g. urinary dipstick test, devices for manual ventilation). Training programme content is described in Table 2.

Health Regional Directors from Oio, Cacheu, Biombo and Farim nominated 14 professionals who provide maternity care to attend the training. Participants filled in an application form, which included demographic and professional data.

A printed handbook organised by training session was made available for each participant at the beginning

Table 2 - Programme content of the Obstetric and Neonatal Urgent Care (CONU) training course

\begin{tabular}{|c|c|c|c|}
\hline & Day & Session content & $\begin{array}{l}\text { Methodology* } \\
\text { (duration in hours) }\end{array}$ \\
\hline \multirow{4}{*}{ 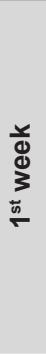 } & \multirow[b]{2}{*}{$1^{\text {st }}$} & $\begin{array}{l}\text { 1. Aseptic issues (good practices). Surgical instruments and equipment to provide maternal } \\
\text { and newborn care (handling, cleaning, disinfection and maintenance). }\end{array}$ & ITS (2h); PS (2h) \\
\hline & & $\begin{array}{l}\text { 2. Organisational factors in urgent situations - levels of provision of care in the health } \\
\text { system: proposals for developing an action plan (referral criteria and patient evacuation - } \\
\text { familiarisation with the evacuation sheet). }\end{array}$ & ITS (4h) \\
\hline & \multirow{2}{*}{$2^{\text {nd }}$} & $\begin{array}{l}\text { 3. Basis of newborn physiology and pathophysiology. Newborn care in the immediate } \\
\text { postpartum period (good practices); Newborn resuscitation (basic life support). }\end{array}$ & ITS (2h); PSS (2h) \\
\hline & & $\begin{array}{l}\text { 4. Leading newborn pathologies; Care of newborns in the first days of life; How to educate } \\
\text { the mother on caring for her child (breastfeeding, hygiene, etc.). }\end{array}$ & ITS (4h) \\
\hline \multirow{4}{*}{ 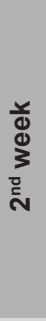 } & \multirow[t]{2}{*}{$3^{\text {rd }}$} & $\begin{array}{l}\text { 5. Haemorrhagic problems of pregnancy }\left(1^{\text {st }}, 2^{\text {nd }}, 3^{\text {rd }} \text { trimesters - abortion, ectopic pregnancy, }\right. \\
\text { hydatidiform mole, placenta disorders); Labour (including different types of presentation) } \\
\text { and partograph. }\end{array}$ & ITS (4h) \\
\hline & & $\begin{array}{l}\text { 6. Care of uneventful vaginal birth; Partograph; Threatened and preterm labour; Premature } \\
\text { rupture of membranes (term and preterm); Foetal lung maturity stimulation. }\end{array}$ & ITS (1h); PSS (3h) \\
\hline & \multirow[t]{2}{*}{$4^{\text {th }}$} & $\begin{array}{l}\text { 7. Labour dystocia (partograph reinforcement); Induction and acceleration of labour; } \\
\text { Instrumented birth. }\end{array}$ & ITS (2h); PSS (2h) \\
\hline & & 8. Intra-partum perineal lacerations and correction technique. Episiotomy and episiorrhaphy. & ITS (1h); PSS (3h) \\
\hline \multirow{4}{*}{ 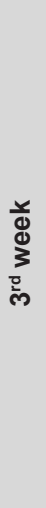 } & \multirow[b]{2}{*}{$5^{\text {th }}$} & $\begin{array}{l}\text { 9. Main conditions associated or related to pregnancy (infections, anaemia, hypertension, } \\
\text { pre-eclampsia, eclampsia, HELLP syndrome, diabetes); Intrauterine growth restriction } \\
\text { (diagnosis, referral, follow up and attitude). }\end{array}$ & ITS (4h) \\
\hline & & $\begin{array}{l}\text { 10. Intra-partum foetal well-being assessment (I); Intermittent (Pinard, cardioscopy) and } \\
\text { continuous foetal heart rate monitoring (basis of cardiotocography - technical aspects, } \\
\text { underlying principles of foetal physiology, parameters used for the classification of } \\
\text { cardiotocographic traces). }\end{array}$ & ITS (4h) \\
\hline & \multirow[b]{2}{*}{$6^{\text {th }}$} & 11.Intra-partum foetal well-being assessment (II). & $\begin{array}{l}\text { PS - }(4 h) \\
\text { clinical cases }\end{array}$ \\
\hline & & $\begin{array}{l}\text { 12. Obstetric emergencies I. Introduction to major emergencies in Obstetrics (red flags, } \\
\text { referral criteria, importance of clinical records / information accompanying the patient who } \\
\text { was referred); simulation-based training of intra-partum critical situations: acute foetal } \\
\text { distress - placenta abruption, eclampsia, maternal cardiac arrest. }\end{array}$ & ITS (2h); PSS (2h) \\
\hline \multirow{3}{*}{ 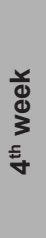 } & \multirow[b]{2}{*}{$7^{\text {th }}$} & $\begin{array}{l}\text { 13. Obstetric emergencies II. Simulation-based training of intra-partum critical situations: } \\
\text { shoulder dystocia, breech birth-head retention, immediate postpartum haemorrhage. }\end{array}$ & ITS (2h); PSS (2h) \\
\hline & & $\begin{array}{l}\text { 14. Obstetric emergencies III. The importance of team work / non-technical aspects in the } \\
\text { resolution of critical situations. Simulation-based training of emergency situations during } \\
\text { pregnancy (ante-partum). Revisions. }\end{array}$ & PSS (4h) \\
\hline & $8^{\text {th }}$ & 15. Normal and surgical puerperium: major complications and red flags. & ITS (4h) \\
\hline
\end{tabular}

* training methodology as follows ITS: interactive theoretical session; PS: practical session; PSS: practical session using simulation 
of the training. It also included an introductory chapter describing the PIMI, the RG-B's maternal and child health-related indicators and a list of obstetric terms used in the subsequent chapters. Theoretical concepts were addressed using a systematic presentation of the issues covered, with demonstrative figures or tables whenever useful. Attitudes or therapeutic options were clearly presented using action plans or algorithms, in line with reliable references in the field, but adapted to local conditions. Additionally, record-keeping documents used in daily practice were included (e.g. partograph, prenatal surveillance card, evacuation sheet).

The team of instructors included an Obstetrics \& Gynecology specialist (pedagogical coordinator) and an Obstetrics \& Gynecology resident. A member of the fixed clinical staff was also involved in five sessions (the first four and the last), per region. The Obstetrics \& Gynecology specialist worked as a member of the clinical rotation staff prior to preparing the training proposal. She also has expertise in intrapartum simulation-based training. ${ }^{6}$ Members of the fixed clinical team had timely access to the syllabus and handbook so that they could provide feedback and prepare the proposed sessions.

The training was planned to run in the facilities of the regional directorates for eight weeks (January 12 to March 6 2015), from Monday to Thursday. Per region, 16 hours were scheduled to run over two consecutive days every couple of weeks, except for the last week in which only 12 hours were held (16 hours x 3 weeks +12 hours $x 1$ week), totalling 60 hours or 15 sessions of four hours (Table 2). Thus, every couple of weeks all regions covered the same topics.

The material and equipment needed for the following week were prepared on Friday, according to a checklist developed for each session. Simulators used included an S500.200 Advanced OB Susie ${ }^{\circledR}$, Gaumard ${ }^{\circledR}$ Scientific, an S500.100 OB Susie ${ }^{\circledR}$, Gaumard ${ }^{\circledR}$ Scientific, a Little Anne ${ }^{\circledR}$, Laerdal $^{\circledR}$ and two Baby Anne ${ }^{\circledR}$, Laerdal ${ }^{\circledR}$.

The sessions were theoretical, though highly interactive, and practical, using demonstrative and simulation-based education techniques applied to healthcare (simulators, patient actors, role play, hybrid simulation, technical skills stations and simulation-based training scenarios with debriefing and self-evaluation of performance based on 'ideal' management checklists).

Trainees signed their presence every session and absences had to be justified.

The trainees were assessed by means of a session-test at the beginning of each session ('formative assessment') and a final-test just after the last session ('summative assessment'). Formative assessment was meant to provide trainees with self-assessment of knowledge, stimulating their interest in the session, as well as to reinforce concepts covered and to prepare participants for the final test regarding type of questions and language. The main purpose of the summative assessment was to evaluate the trainees' level of knowledge (cognition).
The session-test and final-test were prepared after formulating 6 to 10 multiple choice questions on the topics covered in sessions 5 to 14. Each question had 5 options with only one correct answer. These sets of 6 to 10 questions were randomly selected into session-test or finaltest by drawing distinctive labels from a black bag.

Session-test questions were projected one at a time at the beginning of the session ( $5^{\text {th }}$ to $\left.14^{\text {th }}\right)$ and participants recorded their answers on paper. The session questions were shown again immediately after and correct answers provided. The session-test was applied in the last session, but the covered topic was not included in the final-test as both tests were on the same day.

The final-test included 46 questions to answer in 90 minutes. In addition to those covering sessions 5 to 14 , three more questions were added comprising issues of the $3^{\text {rd }}$ and $4^{\text {th }}$ sessions. These additional questions were also randomly selected from a pool of six on the same topic.

Level of satisfaction with the educational intervention ('reactive assessment') was obtained through an anonymous questionnaire completed at the end of the final test. This survey incorporated the following pedagogical variables classified as 'unsatisfactory', 'satisfactory', 'good' or 'very good': instructor's pedagogical skills (adopted teaching methodology, communication skills, standard of knowledge transfer and quality of documentation supplied); training programme content (adequacy of approach to topics, relevance of training for job performance and individual interest); and general feedback from the training (appreciation in terms of the trainees' expectations and overall satisfaction). It also contained open questions related to training programme content: What session interested you most?; What session interested you least?; What other topics would you like to address?; Do you have any suggestions for improving the training? Finally, participants were asked if they thought the course was predominantly 'Theoretical', 'Practical' or 'Theoretical and practical'.

As the research does not include individual or clinical data, ethics approval is not applicable.

\section{RESULTS}

\section{(CONU training achievements)}

The training plan was completed in all regions covered by the PIMI. There were 15 attendees in Oio and Cacheu, 14 in Biombo and 12 in Farim, totalling 56 (25 nurses, 17 midwives and 14 doctors). Within each region, trainees came from various health areas and both regional hospitals.

Regarding participants' attendance, four sessions were missed by six trainees in Oio, five in Cacheu, two in Farim and one in Biombo. Another trainee in Farim and three in Biombo missed two sessions. One trainee missed five sessions in Farim.

Trainees' justifications for absences were: (1) Official move to attend other training (seven trainees who missed four sessions plus two trainees who missed two sessions); (2) Personal affairs (one trainee who missed a session); (3) Coordination functions (one trainee missed two sessions); 
(4) Sickness (one trainee missed two sessions); (5) Death of a close relative (one trainee missed four sessions); (6) Lack of notice to attend the training (one trainee missed two sessions); (7) Judicial notice (one trainee missed four sessions); (8) Replacement (a trainee was replaced after the first four sessions, for unknown reasons). Furthermore, there was a professional who asked to participate even though eight sessions had already elapsed. Another one was added after the first four sessions. In short, of a total of possible 840 presences (56 trainees $\times 15$ sessions), participants missed $69(69 / 840 \times 100=8.2 \%)$. Non-attendance was mostly due to official movement of participants to other courses, 48 in total, representing $69.6 \%$ of all absences $(48 / 69 \times 100)$.

The participants' gender, age, profession and clinical experience are shown in Table 3.

Approximately two thirds of all participants had five or less years of clinical experience and almost half of these a year or less. The final-test results according to the trainee's profession and experience are presented in Table 4.

About two thirds of trainees correctly answered more than half of the final-test questions. The grades obtained apparently correlate with the participants' profession, as doctors got the highest grades, followed by midwives and nurses (Table 4). However, the final-test classification was higher among trainees who mentioned two to nine years of clinical experience (30 out of 54) as compared to those with a year or less or 10 or more years of practice. The analysis of the trainees' experience regarding profession (Table 5) revealed that only $24 \%$ of nurses mentioned clinical practice of two to nine years. Inversely, the majority of midwives and doctors have worked for two to nine years, $(76 \%$ and $78 \%$ respectively).

The attendees' feedback on the pedagogical skills of instructors, training programme content and general satisfaction was very favourable, as the majority rated these Table 3 - Trainees' gender, age, profession and clinical practice $(n=56)$

\begin{tabular}{|c|c|c|}
\hline & & $\mathbf{n}$ \\
\hline లั & $\begin{array}{l}\text { Female } \\
\text { Male }\end{array}$ & $\begin{array}{l}41(73.2 \%) \\
15(26.8 \%)\end{array}$ \\
\hline 㐫 & $\begin{array}{c}\text { median (min - max) } \\
\text { average }\end{array}$ & $\begin{array}{l}36(24-59) \\
36.8\end{array}$ \\
\hline 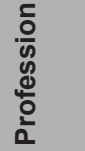 & $\begin{array}{l}\text { Nurse } \\
\text { Midwife } \\
\text { Doctor }\end{array}$ & $\begin{array}{l}25(44.6 \%) \\
17(30.4 \%) \\
14(25.0 \%)\end{array}$ \\
\hline 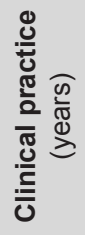 & $\begin{array}{c}\leq 1 \\
2 \text { to } 5 \\
6 \text { to } 9 \\
\geq 10 \text { years } \\
N^{*} \\
\text { median (min - max) } \\
\text { average }\end{array}$ & $\begin{array}{l}17(30.4 \%) \\
19(33.9 \%) \\
11(19.6 \%) \\
7(12.5 \%) \\
2(3.6 \%) \\
3(0.4-43) \\
6.5\end{array}$ \\
\hline
\end{tabular}

n: number of trainees; \%: percentage of trainees; ${ }^{*} \mathrm{NA}$ : no answer

Table 4 - Trainees' final-test results (\% of correct answers of 46 questions) according to profession and clinical practice

\begin{tabular}{|c|c|c|c|c|c|c|}
\hline & $\begin{array}{l}<49 \% \\
n\end{array}$ & $\begin{array}{l}\geq \mathbf{5 0} \% \\
n\end{array}$ & $\begin{array}{l}\text { Minimum } \\
\%\end{array}$ & $\begin{array}{l}\text { Maximum } \\
\%\end{array}$ & $\begin{array}{l}\text { Median } \\
\%\end{array}$ & $\begin{array}{l}\text { Average } \\
\%\end{array}$ \\
\hline \multicolumn{7}{|c|}{ Profession $(n=56)$} \\
\hline Nurse & 14 & 11 & 17.4 & 67.4 & 45.7 & 44.4 \\
\hline Midwife & 7 & 10 & 39.1 & 80.4 & 50.0 & 53.8 \\
\hline Doctor & 0 & 14 & 54.4 & 87.0 & 73.9 & 72.1 \\
\hline Overall & $21^{*}$ & $35^{\star *}$ & 17.4 & 87.0 & 53.3 & 54.2 \\
\hline \multicolumn{7}{|c|}{ Clinical practice $(n=54)^{* * *}$} \\
\hline$\leq 1$ & 9 & 8 & 26.1 & 76.1 & 47.8 & 49.6 \\
\hline 2 to 5 & 3 & 16 & 17.4 & 87.0 & 60.9 & 61.2 \\
\hline 6 to 9 & 4 & 7 & 39.1 & 80.4 & 54.4 & 57.1 \\
\hline$\geq 10$ & 4 & 3 & 23.9 & 65.2 & 45.7 & 44.4 \\
\hline Overall & 20 & 34 & 17.4 & 87.0 & 53.3 & 54.6 \\
\hline
\end{tabular}

n: number of trainees; ${ }^{*} 37.5 \%$ of all trainees; ${ }^{* *} 62.5 \%$ of all trainees; ${ }^{* *} 2$ trainees did not answer

Table 5 - Trainees' clinical practice according to profession

\begin{tabular}{|c|c|c|c|c|c|c|}
\hline & \multicolumn{6}{|c|}{$\begin{array}{l}\text { Clinical practice } \\
\text { years }\end{array}$} \\
\hline & $\begin{array}{l}\leq 1 \\
\mathrm{n}(\%)\end{array}$ & $\begin{array}{l}2 \text { to } 5 \\
\mathrm{n}(\%)\end{array}$ & $\begin{array}{l}6 \text { to } 9 \\
\mathrm{n}(\%)\end{array}$ & $\begin{array}{l}\geq 10 \\
\mathrm{n}(\%)\end{array}$ & $\begin{array}{l}\mathbf{N A}^{*} \\
\mathrm{n}(\%)\end{array}$ & $\begin{array}{l}\text { Overall } \\
\mathrm{n}(\%)\end{array}$ \\
\hline \multicolumn{7}{|c|}{ Profession } \\
\hline Nurse & $15(60.0)$ & $6(24.0)$ & $0(0.0)$ & $3(12.0)$ & $1(4.0)$ & $25(100)$ \\
\hline Midwife & $0(0.0)$ & $2(11.8)$ & $11(64.7)$ & $4(23.5)$ & $0(0.0)$ & $17(100)$ \\
\hline Doctor & $2(14.3)$ & $11(78.6)$ & $0(0.0)$ & $0(0.0)$ & $1(7.1)$ & $14(100)$ \\
\hline
\end{tabular}

n: number of trainees; \%: percentage of trainees within each profession; ${ }^{*} \mathrm{NA}$ : no answer 
variables as 'good' or 'very good' $(91 \%, 95 \%$ and $91 \%$, respectively). All students but one commented or made suggestions. The vast majority noted that they enjoyed the training a lot, thanked us, asked us to extend the training and highlighted the need to schedule retraining. Trainees also mentioned that the covered topics were all interesting, and none was less important than others.

Finally, $91 \%$ (51 out of 56 ) of participants considered the educational intervention as predominantly 'Theoretical and practical' or 'Practical'.

\section{DISCUSSION}

\section{Training development challenges - lessons learned}

Planning, implementation and execution of the 'CONU' training was challenging as this intervention is part of a far more comprehensive programme, the PIMI, aimed at reducing maternal and under-five mortality in the RG-B. Regarding maternal and child health, this country is under a humanitarian emergency, as previously highlighted. ${ }^{1,2}$

Commenting on an article about the challenges of implementing a mentoring programme on reform and management of the health system in a province in Mozambique, Lapão $\mathrm{LV}^{7}$ an author with vast experience in African Portuguese-speaking countries, stressed that in order to define capacity strengthening needs in these settings, it is crucial to adapt training to the existing reality. $\mathrm{He}$ also emphasised that the organisation of the training has specific requirements such as coordination with local entities, awareness of the heterogeneity of human resources (shortage and expertise) and available equipment, as well as of a health system organisation dealing with serious weaknesses in the referral system, among many other issues. All of these challenges were well perceived.

The aspects considered in developing and conducting the training were the prevalence and incidence of the patients' conditions, local legislation, adopted guidelines and clinical record forms, the convenience of participants in attending the training considering their mobility and (minimal) impact on daily clinical activities, mobility of the training team and material and equipment, potential communication barriers between trainees and instructors, cultural issues, financial issues, ongoing programmes with similar or complementary goals and, importantly, recognition of existing constraints to effectively operate a health system based on levels of differentiation. The pedagogical coordinator collaboration in capacity building 'on-the-job' missions prior to preparing the training proposal was very useful in anticipating these difficulties. Though training had been scheduled with local authorities, the official movement of participants to attend other courses was the main reason given for the absences.

The CONU occurred halfway through the PIMI so it was felt it might be wise to include members of the fixed clinical team in the instruction. They had already started, and continued, to convey concepts covered 'on the job' and had built a closer relationship with the participants.

Every week, training was scheduled to run in two regions. This required the preparation of checklists and boxes for material and equipment to support practical sessions. Sessions took place in the facilities of the Regional Directorates for closer proximity with the trainees, as some of them came from remote areas. This entailed visiting available facilities in advance and demanded a lot of effort from the training team and IMVF-PIMI resources. The room available for training was one for local meetings, so instructors had to arrive early, 30 - 45 minutes before the start of sessions, to prepare the area, set up equipment and organise pedagogical records (e.g. attendance sheets). Reliance on a diesel generator in order to use projectors was the cause of some delays.

The space available for training was quite small in all but one region, forcing us to run some training stations on the terrace or in the corridor. Although this required adaptability on the part of the trainer and trainees, it did not interfere in the running of the programme. It was useful for encouraging improvisation skills in carrying out actual clinical tasks, creating an educational experience closer to reality and boosting empathy among the trainees. The strong interactive component fostered throughout the course allowed a comprehensive overview of local healthcare.

Regional Directorates are located within hospital premises in two regions, so a few attendees were sometimes called out to manage emergency cases. As a result, the instructors were asked to help resolve two intrapartum emergencies (placental abruption and second twin in transverse lie in a vaginal birth). In fact, although running simulation-based training at the workplace can lead to dispersion of the participants, in this case it was also beneficial since aspects related to these cases were addressed, resulting in a fruitful pedagogical experience.

The syllabus was prepared in accordance with established goals and the target audience, but it also took into account complementarity and reinforcement of concepts, techniques, and attitudes throughout the sessions. Simulators were chosen once the programme content had been defined as well as according to their portability, operation without electricity (manual or batteries), their initial cost and that of consumables.

The groups of trainees included only 12 to 15 participants per region to fulfil a maximum ratio of $7-8$ trainees per training station or simulated exercise ('hands on'), in addition to budget constraints, as local law dictates that attendees should receive a daily allowance for travel and food (per diem).

Overall, as expected, selected trainees were mostly nurses and health professionals with five years' practice or less, but there were also participants with less than one year and more than 10 years of experience. Mixing different professions and experience backgrounds seemed very useful. It encouraged the exchange of ideas among participants, on clinical practice and on how the local health system functions, in addition to promoting the concept of school 'on the job'.

The trainees' assessment was formative (sessiontest), summative (final-test) and reactive by applying an 
anonymous satisfaction questionnaire just after the finaltest. Self-evaluation of knowledge was extremely useful. It stimulated the trainees' interest in the session and was central to preparing the participants for the final-test regarding type of questions, language and/or obstetric terminology. Despite running the course in Portuguese, some communication constraints due to language difficulties were noticed during training. In fact, the most commonly spoken language is Creole. Additionally, most health professionals attained their degree in Spanish ${ }^{8}$ or other languages apart from Portuguese, creating some confusion regarding health terminology.

Participant satisfaction with the training was very positive and rewarding. Willingness to continue and schedule retraining was clearly expressed. Training was deemed eminently practical, which was attained by using simulation-based training techniques. As reported in the literature $^{6}$, this learning methodology was perceived as helping to decrease the gap between theoretical concepts and practice, albeit 'simulated practice'. It also provided an atmosphere for sharing knowledge, attitudes and ideas for improving clinical practice.

\section{Factors that may affect the impact of training}

Recognising that CONU is part of a much larger intervention programme (PIMI) is of utmost importance. This precludes medium- to long-term assessment of the impact of training as we cannot separate achievements made as a result of the training from those ensuing from 'on-the-job' capacity building, carried out on a daily basis.

The analysis of the training impact was hampered by the fact that the health professionals involved had varying degrees of qualifications and experience. Additionally, the participants were chosen by the regional health directors. This type of selection precludes the generalisation of results, as attendees might not represent all fields of health care from the target regions. However, the health professions providing prenatal and intra-partum care in the RG-B were all represented, i.e. nurses, midwives and doctors, coming from both regional hospitals and different types of health units.

Both session- and final-tests were prepared after randomly dividing a set of multiple choice questions on the topics covered so as to standardise difficulty and type of questions (theoretical concepts versus theoretical practice) for the final-test.

The main goal of the 'summative' assessment was to distinguish trainees in terms of their level of knowledge (cognition). However, differences in the participants' ability to understand the information conveyed (language and terminology) or in the trainees' aptitude to answer multiple choice questions may hinder this analysis.

Almost two thirds of the trainees correctly answered more than half the final-test questions. Apparently, finaltest results seem to discriminate participants regarding their profession. However, this finding cannot be separated from professional experience as nurses comprised the vast majority of participants, with a year or less of practice. Unexpectedly, four out of seven midwives and nurses reporting 10 or more years of clinical practice obtained less than $50 \%$ in the final-test. This result most likely reflects the reduced number of cases in the study. The final-test results obtained indicate the need to adapt the training programme for professionals with a year or less of practice.

It would be interesting to evaluate the impact of the educational intervention on technical and non-technical skills, but the course would need to be lengthened. However, cognition (factual knowledge) is the foundation for acquiring higher level skills for clinical practice and its assessment seemed valuable for choosing a small group of participants that could be trained in the near future as local instructors. In a systematic review ${ }^{9}$ including 41 randomised controlled trials, the authors concluded that interventions to improve health worker performance in Sub-Saharan Africa can be very effective, with a significant reduction in in-hospital maternal and under-5 mortality. However, some contextual factors seem to interfere with the impact of the interventions, such as failure to follow up training interventions with ongoing support allied to staff turnover, supply-line failures and inadequate supervision or management. Our perspective goes in line with the findings of this review. Thus, depending on the location of the intervention, contextual factors capable of modifying the impact of interventions on the goals to achieve should be clearly identified and assessed.

\section{Usefulness of specific training on maternal and newborn care in the RG-B}

Similarly to other comparable settings, ${ }^{3,10,11}$ there are many barriers in the RG-B to timely access to emergency obstetric care services, leading to poor perinatal and maternal outcomes. A systematic review ${ }^{11}$ aiming to identify specific facility-level barriers for women accessing emergency obstetric care in developing countries, known as the 'third delay', found that inadequate training/skills mix was the most frequently reported constraint $(86 \%$ of 43 selected papers) followed by drug procurement/logistics problems $(65 \%)$, staff shortages $(60 \%)$, lack of equipment $(51 \%)$ and low staff motivation (44\%). The obtained results highlighted the importance of focusing on supplyside barriers, particularly on issues related to healthcare staff training/skills and shortages, if further reductions in maternal mortality are to be achieved. In a cross-sectional survey designed to identify predictors of in-hospital maternal mortality among 89518 women who delivered in 46 referral hospitals in Mali and Senegal, ${ }^{3}$ the authors suggested that due to the shortage of doctors and midwives even less-qualified health staff (students, matrons, nurse assistants) should be trained in early detection of obstetric complications highly predictive of in-hospital maternal death, such as uterine rupture and ante/immediate postpartum haemorrhage.

Due to a health workforce shortage, Timor-Leste official entities decided to implement strategies for scalingup health professionals. ${ }^{12}$ In cooperation with Cuba, they 
supported university undergraduate education of doctors, nurses and midwives. Unsurprisingly, a systematic review ${ }^{13}$ using national survey data from 41 African countries, including Guinea-Bissau, concluded there was a negative correlation of percentage of births attended by skilled health personnel with maternal mortality, stillbirths and neonatal mortality. The same authors found, in a meta-analysis, ${ }^{14}$ a significant reduction in perinatal mortality among women who attended antenatal care in developing nations.

Though many other factors may interfere with reproductive health outcomes, the results obtained indicate the need for capacity building interventions for health professionals in the provision of maternal and newborn care in countries like the RG-B.

\section{CONCLUSION}

In conclusion, the CONU training course comprised highly interactive, practical, simulation-based in-class training, held in four regions of the RG-B, which ran under a programme including a strong, continuous, component of 'on-the-job' capacity building of health staff. This fact, in itself, hinders evaluation of the training impact on learning or clinical outcomes. However, we believe that the impact of the programme would not be the same without this educational intervention.

- CONU training has been perceived as helpful as it allowed increased involvement of end beneficiaries regarding PIMI goals.

- Opting for a highly interactive/practical ('hands on') pedagogical methodology was considered more suitable for participants who face clinical situations on a daily basis. It also allowed training to be adapted to local resources. However, extending the training to professionals with a year or less of practice might be needed.

- When running a training course in a foreign, low- resource country we should build a predisposition for improvisation, facing difficulties as teaching/ learning opportunities. Tolerance for different backgrounds and cultures is mandatory.

- Interventions to scale up healthcare professionals in the RG-B as well as their expertise in maternal-foetal and neonatal health are needed if improvement of maternal, perinatal and newborn outcomes is the goal. Nevertheless, evaluation of the training impact should be made feasible.

\section{ACKNOWLEDGMENTS}

Sincere thanks to all the staff taking part in the IMVF initiatives under the PIMI. Without their ready availability and helpfulness, the training would not have been possible. Also, very warm thanks to the trainees for embracing our teaching methodologies so enthusiastically and for their tremendous motivation, which made it an unforgettable experience.

\section{PROTECTION OF HUMANS AND ANIMALS}

The authors declare that the procedures were followed according to the regulations established by the Clinical Research and Ethics Committee and to the Helsinki Declaration of the World Medical Association.

\section{DATA CONFIDENTIALITY}

The authors declare having followed the protocols in use at their working center regarding patient's data publication.

\section{CONFLICTS OF INTEREST}

The authors report no conflict of interest.

\section{FUNDING SOURCES}

There were no sources of funding specifically for the research.

health system strengthening in Zambézia Province, Mozambique”. Int J Health Policy Manag. 2015;4:691-3.

8. Ferrinho P, Sidat M, Fresta MJ, Rodrigues A, Fronteira I, Silva F, et al The training and professional expectations of medical students in Angola, Guinea-Bissau and Mozambique. Hum Resour Health. 2011;9:9.

9. Blacklock C, Gonçalves Bradley DC, Mickan S, Willcox M, Roberts $\mathrm{N}$, Bergström A, et al. Impact of contextual factors on the effect of interventions to improve health worker performance in Sub-Saharan Africa: review of randomised clinical trials. PLoS One. 2016;11:e0145206.

10. Jammeh A, Sundby J, Vangen S. Barriers to emergency obstetric care services in perinatal deaths in rural Gambia: a qualitative in-depth interview study. ISRN Obstet Gynecol. 2011;981096.

11. Knight HE, Self A, Kennedy SH. Why are women dying when they reach hospital on time? A systematic review of the 'Third delay'. PLoS One. 2013;8:e63846.

12. Ferrinho $P$, Valdes $A C$, Cabral J. The experience of medical training and expectations regarding future medical practice of medical students in the Cuban-supported Medical School in Timor-Leste. Hum Resour Health. 2015;13:13.

13. Berhan Y, Berhan A. Skilled health personnel attended delivery as a proxy indicator for maternal and perinatal mortality: a systematic review. Ethiop J Health Sci. 2014;24:69-80.

14. Berhan Y, Berhan A. A meta-analysis of selected maternal and fetal factors for perinatal mortality. Ethiop J Health Sci. 2014;24:55-68. 